\title{
Synthesis of $\mathrm{Rh}_{6}(\mathrm{CO})_{16}$ in Supercages of Zeolite
}

\section{HY: Reaction Network and Kinetics of Formation}

\section{from Mononuclear Rhodium Precursors via}

\section{$\mathrm{Rh}_{4}(\mathrm{CO})_{12}$ Facilitated by the Water Gas Shift}

\section{Half-Reaction}

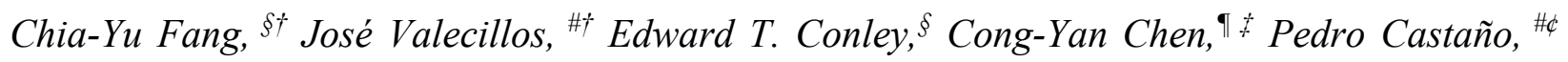
Bruce C. Gates t* $^{*}$

$\S^{\S}$ Department of Materials Science and Engineering, University of California, Davis, California 95616, United States

"Department of Chemical Engineering, University of the Basque Country (UPV/EHU), P.O. Box 644, E48080, Bilbao, Spain

${ }^{\top}$ Chevron Energy Technology Company, 100 Chevron Way, Richmond, California 94892, United States

Department of Chemical Engineering, University of California, Davis, California 95616, United States

${ }^{\varphi}$ Multiscale Reaction Engineering, KAUST Catalysis Center (KCC), King Abdullah University of Science and Technology (KAUST), Thuwal, 23955-6900, Saudi Arabia 


\begin{abstract}
$\mathrm{Rh}(\mathrm{I})(\mathrm{CO})_{2}$ complexes anchored to zeolite $\mathrm{HY}$ were converted into $\mathrm{Rh}_{4}(\mathrm{CO})_{12}$ in the zeolite supercages upon exposure to flowing $\mathrm{CO}+\mathrm{H}_{2} \mathrm{O}$ at $35^{\circ} \mathrm{C}$, and the chemistry and kinetics were characterized with infrared (IR) spectroscopy. $\mathrm{Rh}_{6}(\mathrm{CO})_{16}$ formed along with $\mathrm{Rh}_{4}(\mathrm{CO})_{12}$, but only in low yield, although it is more stable than $\mathrm{Rh}_{4}(\mathrm{CO})_{12}$. The formation of $\mathrm{Rh}_{6}(\mathrm{CO})_{16}$ was hindered by trapping of $\mathrm{Rh}_{4}(\mathrm{CO})_{12}$ in the supercages and by the low rate of transport of the mononuclear rhodium species. However, exposure of the sample to wet helium at $80{ }^{\circ} \mathrm{C}$ caused the $\mathrm{Rh}_{4}(\mathrm{CO})_{12}$ to fragment, generating anchored $\mathrm{Rh}(\mathrm{I})(\mathrm{CO})_{2}$ and also $\mathrm{Rh}_{6}(\mathrm{CO})_{16}$. IR spectra recorded under various conditions led to elucidation of the reaction network for cluster formation and breakup and a strategy of repetitive treatments that boosted the yield of $\mathrm{Rh}_{6}(\mathrm{CO})_{16}$ to $>90 \%$. The reversible formation and breakup of the rhodium carbonyl clusters were facilitated by the half-reactions of the water gas shift reaction, with gas-phase products identified by mass spectrometry. The results show how understanding of the reactions within a zeolite allows control of the nuclearity of encaged metal clusters, an important class of catalyst.
\end{abstract}

\title{
INTRODUCTION
}

Metal clusters and nanoparticles encapsulated in zeolites are an important class of catalyst, exemplified by platinum in faujasite zeolites used for hydrocracking, dehydrocyclization, and hydroisomerization of alkanes. ${ }^{1-5}$ Because typical zeolite-supported metal clusters are nonuniform in size, shape, and interactions with supports, their structural characterization is challenging; further, the chemistry of their formation remains largely uncharacterized. Such materials are typically made by adsorption or ion exchange to anchor cationic metals, followed by reduction accompanied by metal migration and aggregation, ${ }^{6}$ with the zeolite cages in some instances 
limiting the sizes of the metal species (in ship-in-a-bottle syntheses), ${ }^{7}$ although reduction under forcing conditions may lead to the breakup of the porous zeolite structure as metal particles expand and break it apart. ${ }^{8}$

Early work on precise synthesis of metal clusters in zeolite cages involved ship-in-a-bottle syntheses from single-metal-atom (mononuclear) precursors. ${ }^{9}$ Clusters made in this way include those of the catalytically important metals rhodium and iridium; the clusters include some known from molecular organometallic chemistry: $\mathrm{Rh}_{4}(\mathrm{CO})_{12},{ }^{10} \mathrm{Rh}_{6}(\mathrm{CO})_{16},{ }^{11} \operatorname{Ir}_{4}(\mathrm{CO})_{12},{ }^{12}$ and $\operatorname{Ir}_{6}(\mathrm{CO})_{16},{ }^{13}$ each made in the supercages of faujasite zeolites.

The principal goal of the work reported herein was to understand the chemistry of formation of $\mathrm{Rh}_{6}(\mathrm{CO})_{16}$ clusters from a structurally well-defined precursor, $\mathrm{Rh}(\mathrm{I})(\mathrm{CO})_{2}$ in $\mathrm{HY}$ zeolite - which incorporates supercages just the right size to trap the clusters. A low-silica zeolite $\mathrm{HY}(\mathrm{Si}$ :Al atomic ratio $=2.6)$, which offers a high density of surface bonding sites $(\mathrm{OH}$ groups at Al sites), was chosen to facilitate the formation of $\mathrm{Rh}_{6}(\mathrm{CO})_{16} .{ }^{10}$ The precursor was made by chemisorption of $\mathrm{Rh}(\mathrm{I})(\mathrm{CO})_{2}(\mathrm{acac})$ on the zeolite, as reported, ${ }^{14}$ and $\mathrm{Rh}_{4}(\mathrm{CO})_{12}$ was identified as an intermediate in the synthesis of $\mathrm{Rh}_{6}(\mathrm{CO})_{16}$, with the kinetics of cluster formation determined by infrared (IR) spectroscopy bolstered with and X-ray absorption spectroscopy. The cluster formation was found to be reversible and coupled with the catalytic water gas shift reaction. The data reported herein are the first showing how to precisely control the nuclearity of the anchored rhodium species.

\section{MATERIALS AND METHODS}

Synthesis of $\mathbf{R h}(\mathbf{I})(\mathbf{C O})_{2}$ in zeolite $\mathbf{H Y}$. With all reagents and materials handled with standard moisture- and air-exclusion methods, dealuminated HY zeolite samples having Si:Al 
atomic ratios of 2.6 or 30 (Zeolyst International CBV600 or CBV760, respectively) were calcined in flowing $\mathrm{O}_{2}$ in a once-through plug-flow reactor at $500{ }^{\circ} \mathrm{C}$ for $4 \mathrm{~h}$ followed by treatment under vacuum at the same temperature for $12 \mathrm{~h}$. One gram of the calcined zeolite was slurried with $13 \mathrm{~g}$ of the precursor $\mathrm{Rh}(\mathrm{I})(\mathrm{CO})_{2}(\mathrm{acac})$ (acac is acetylacetanato) $(99 \%$, Strem) in $30 \mathrm{~mL}$ of dried, deoxygenated $n$-pentane (reagent grade, $98 \%$, Sigma-Aldrich). The molarity of rhodium in the $n$ pentane was $1.7 \mathrm{~mol} / \mathrm{L}$. The slurry was stirred under argon at room temperature for $24 \mathrm{~h}$, followed by removal of the $n$-pentane by overnight evacuation. In this synthesis, all of the rhodium was retained by the zeolite. Each sample, with a rhodium loading of $0.50 \mathrm{wt} \%$, was stored in an argonfilled glovebox.

Infrared spectroscopy. IR spectra of the rhodium-containing samples were recorded with a Bruker IFS 66v/S spectrometer with a resolution of $4 \mathrm{~cm}^{-1}$. Approximately $30 \mathrm{mg}$ of each sample was pressed into a self-supported wafer and loaded into an IR cell (In-situ Research Instruments Inc., South Bend, IN) through which gases flowed, including $\mathrm{CO}$ and/or helium, which in some experiments flowed through gas-liquid contactors held at $25^{\circ} \mathrm{C}$ to saturate them with deionized water, giving a water concentration predicted by vapor-liquid equilibrium data to be $3.1 \mathrm{~mol} \%$. Transmission IR spectra of the solid samples were recorded as they were in contact with the flowing gases. Each spectrum is the average of 64 scans.

Mass spectrometry. Gas-phase products formed from samples in the IR cell flowed for analysis to an on-line mass spectrometer (Balzers Omnistar) running in multi-ion detection mode. Data were collected periodically as IR spectra of the solid samples were recorded.

X-ray absorption spectroscopy. X-ray absorption spectra, including X-ray absorption near edge spectra (XANES) and extended X-ray absorption fine structure (EXAFS) spectra, were recorded to characterize the solid samples in various flowing gases. The experiments were done at 
beamline 4-1 of the Stanford Synchrotron Radiation Lightsource (SSRL). This is a high-flux beamline optimized for both soft and hard X-ray absorption spectroscopy. The storage ring energy and current were $3 \mathrm{GeV}$ and $500 \mathrm{~mA}$, respectively. A double-crystal $\mathrm{Si}(220)$ monochromator was detuned by $20 \%$ at the rhodium $\mathrm{K}$ edge to minimize higher orders of harmonic diffraction from the monochromator. EXAFS spectra were collected with a Lytle detector, with an air-tight flowthrough cell ${ }^{15}$ mounted for fluorescence detection. Typically, $400 \mathrm{mg}$ of a rhodium-containing sample was loaded into the cell in an argon-filled glovebox at SSRL and transferred to the beamline without air exposure. Spectra were recorded with samples in the presence of flowing gases, including $\mathrm{CO}$ and helium, sometimes flowing through a gas-liquid contactor containing water and held at a temperature of $25^{\circ} \mathrm{C}$. For calibration, a rhodium foil reference sample was placed between the upbeam and downbeam ion chambers so that its spectrum was measured simultaneously with that of the sample.

Analysis of EXAFS results. Analysis of the EXAFS data was carried out with Athena of the software package Demeter and with the software XDAP. Athena was used for edge calibration and deglitching. XDAP was used for background removal, normalization, and conversion of the data into an EXAFS function file. Reference backscattering phase shifts were calculated from crystallographic data determined with the software FEFF7. We use the term $\mathrm{Rh}-\mathrm{O}_{\mathrm{s}}$ to denote rhodium-oxygen shells corresponding to rhodium bonded to the zeolite framework. These contributions were calculated on the basis of the structural parameters of $\mathrm{Rh}(\mathrm{I})(\mathrm{CO})_{2}(\mathrm{acac})$. We use the terms $\mathrm{C}^{\mathrm{t}}$ and $\mathrm{C}^{\mathrm{b}}$ to denote carbon atoms of terminal and bridging carbonyl ligands, respectively, and $\mathrm{O}^{t}$ and $\mathrm{O}^{\mathrm{b}}$ to denote oxygen atoms of those ligands, respectively. The $\mathrm{Rh}-\mathrm{Rh}$, $\mathrm{Rh}-\mathrm{C}^{\mathrm{t}}, \mathrm{Rh}-\mathrm{C}^{\mathrm{b}}, \mathrm{Rh}-\mathrm{O}^{\mathrm{t}}$, and $\mathrm{Rh}-\mathrm{O}^{\mathrm{b}}$ contributions were calculated with Artemis for $\mathrm{Rh}_{4}(\mathrm{CO})_{12}$. Multiple backscattering paths in Rh-CO moieties were considered in the analyses. The 
coordination numbers characterizing a $\mathrm{Rh}-\mathrm{C}$ contribution (the backscatterer is a carbon atom of a terminal or bridging $\mathrm{CO}$ ligand) and a $\mathrm{Rh}-\mathrm{O}$ contribution (the backscatterer is an oxygen atom of a terminal or bridging $\mathrm{CO}$ ligand) were constrained to be the same in the fitting. In the fitting, values of $\Delta E_{0}$ in each scattering path were constrained. The number of parameters used in the fitting was always less than the statistically justified number, computed with the Nyquist theorem: $n=2 \Delta k \Delta r / \pi+1$ (where $\Delta k$ and $\Delta r$, respectively, are the ranges in the wave vector and distance in real space used in the fitting).

Fitting was done by an iterative process with a "difference-file" technique to determine a model comparing the data with both the overall fits and the fits of individual shells. Each recommended model is a best-fit model chosen as the one among a set of plausible candidate models making good chemical and physical sense determined with consideration of both the $k^{1}$ and $k^{3}$-weighted EXAFS data; the Fourier-transformed data representing the overall fit; and the Fourier-transformed data characterizing each shell contribution —-when all of these were in best agreement with the calculated fits. The quality of a fit was evaluated by the value of goodness of fit, defined below:

$$
\text { Goodness of fit }=\frac{v}{\operatorname{NPTS}\left(v-N_{\text {free }}\right)} \sum_{i=1}^{N P T S}\left(\frac{\exp , i \quad \operatorname{model}, i}{\exp , i}\right)^{2}
$$

where $\chi_{\exp }$ and $\chi_{\text {model }}$ are the experimental and calculated EXAFS functions, respectively; $\sigma_{\exp }$ the error in the experimental results; $v$ the number of independent data points in the fit range; $N_{\text {free }}$ the number of free parameters; and NPTS the number of data points in the fit range.

\section{RESULTS}


Synthesis of $\mathbf{R h}(\mathbf{I})(\mathbf{C O})_{2}$ anchored in zeolite $\mathbf{H Y}$. Isolated $\mathrm{Rh}(\mathrm{I})(\mathrm{CO})_{2}$ complexes were incorporated as reported elsewhere ${ }^{14}$ into zeolite $\mathrm{HY}$ with a Si:Al atomic ratio of 2.6 by the reaction of the $\mathrm{Rh}(\mathrm{I})(\mathrm{CO})_{2}(\mathrm{acac})$ precursor in $n$-pentane solution with the zeolite. The rhodium became anchored by reaction with Brønsted-acidic $\mathrm{OH}$ groups in the zeolite, as shown by the decreases in intensity of the IR bands characterizing these groups (Figure S1(a) in the SI). The IR spectra (Figure S1(b) in the SI) of the zeolite containing the anchored rhodium species are characterized by two pairs of bands in the $v_{\mathrm{CO}}$ region, centered at 2117 and 2053 and at 2108 and $2043 \mathrm{~cm}^{-1}$. These indicate $\mathrm{Rh}(\mathrm{I})(\mathrm{CO})_{2}$, as confirmed with EXAFS data (Table 1) published elsewhere. ${ }^{14}$ The IR data imply the presence of two types of $\mathrm{Rh}(\mathrm{I})(\mathrm{CO})_{2}$. To verify the identity of the $\mathrm{Rh}(\mathrm{I})(\mathrm{CO})_{2}$ species, we exposed the sample to a pulse of ${ }^{13} \mathrm{CO}$ in helium at room temperature. The spectrum (Figure $\mathrm{S} 2$ in the $\mathrm{SI}$ ) gave evidence of $\mathrm{Rh}(\mathrm{I})\left({ }^{12} \mathrm{CO}\right)\left({ }^{13} \mathrm{CO}\right)$, consistent with the harmonic approximation, verifying the identification of $\mathrm{Rh}(\mathrm{I})(\mathrm{CO})_{2}$. Thus, the peaks at 2117 and $2053 \mathrm{~cm}^{-1}$ are assigned ${ }^{16}$ to the $\mathrm{C}-\mathrm{O}$ vibrational modes of $\mathrm{Rh}(\mathrm{I})(\mathrm{CO})_{2}$ species bonded at the isolated framework aluminum sites where $\mathrm{OH}$ groups were present. The other pair, observed at lower frequencies, 2108 and $2043 \mathrm{~cm}^{-1}$, indicates a second type of $\mathrm{Rh}(\mathrm{I})(\mathrm{CO})_{2}$ species bonded at sites having higher electron-donating ability (and weaker Brønsted acidity) than the others, ${ }^{17}$ and we suggest that they were present at framework aluminum sites having more than one secondneighbor aluminum site.

These results are evidently in contrast to those characterizing $\mathrm{Rh}(\mathrm{I})(\mathrm{CO})_{2}$ anchored in zeolite HY with atomic $\mathrm{Si}$ Al ratios greater than 15 , which primarily incorporate isolated framework aluminum sites - for these, only sharp, symmetrical C-O IR bands, at 2117 and 2053 $\mathrm{cm}^{-1}$, were observed. ${ }^{16}$ 
Table 1. EXAFS fitting parameters ${ }^{(l)}$ of $\mathrm{Rh}_{6}(\mathrm{CO})_{16}$ synthesized from $\mathrm{Rh}(\mathrm{I})(\mathrm{CO})_{2}$ complexes in zeolite HY ( $\mathrm{Si}: \mathrm{Al}$ atomic ratio $=2.6)$ and comparison with crystallographic data characterizing $\mathrm{Rh}_{6}(\mathrm{CO})_{16}$.

\begin{tabular}{|c|c|c|c|c|c|c|c|c|}
\hline \multirow[t]{3}{*}{ Supported species } & \multirow[t]{3}{*}{ Shell $^{(2)}$} & \multirow{2}{*}{\multicolumn{4}{|c|}{ EXAFS parameters }} & \multirow{2}{*}{\multicolumn{2}{|c|}{$\begin{array}{l}\text { Crystallographic } \\
\text { parameters for pure } \\
\mathrm{Rh}_{4}(\mathrm{CO})_{12} \text { and } \\
\mathrm{Rh}_{6}(\mathrm{CO})_{16} 18,19\end{array}$}} & \multirow[t]{3}{*}{ Ref. } \\
\hline & & & & & & & & \\
\hline & & $\mathrm{CN}$ & $R(\AA)$ & $\Delta \sigma^{2} \times 10^{3}\left(\AA^{2}\right)$ & $\Delta E_{0}(\mathrm{eV})$ & $\mathrm{CN}$ & $R(\AA)$ & \\
\hline \multirow[t]{4}{*}{$\mathrm{Rh}(\mathrm{I})(\mathrm{CO})_{2}$} & $\mathrm{Rh}-\mathrm{O}_{\mathrm{s}}$ & 2.4 & 2.13 & 0.84 & -0.6 & & & \multirow[t]{4}{*}{10} \\
\hline & $\mathrm{Rh}-\mathrm{O}_{1}$ & 1.9 & 2.76 & 0.39 & -6.4 & & & \\
\hline & $\mathrm{Rh}-\mathrm{C}_{\mathrm{t}}$ & 1.9 & 1.84 & 2.03 & 10.0 & & & \\
\hline & $\mathrm{Rh}-\mathrm{O}_{\mathrm{t}}$ & 2.2 & 2.99 & 2.41 & -7.4 & & & \\
\hline \multirow[t]{5}{*}{$\mathrm{Rh}_{4}(\mathrm{CO})_{12}$} & $\mathrm{Rh}-\mathrm{Rh}$ & 3.0 & 2.72 & 7.28 & -6.8 & 3.0 & 2.70 & \multirow[t]{5}{*}{6} \\
\hline & $\mathrm{Rh}-\mathrm{C}^{\mathrm{t}}$ & 2.2 & 1.91 & 8.31 & 1.81 & 2.2 & 1.90 & \\
\hline & $\mathrm{Rh}-\mathrm{C}^{\mathrm{b}}$ & 1.5 & 2.12 & 6.12 & -5.49 & 1.5 & 2.10 & \\
\hline & $\mathrm{Rh}-\mathrm{O}^{\mathrm{t}}$ & 2.2 & 3.03 & 6.33 & -1.58 & 2.2 & 3.05 & \\
\hline & $\mathrm{Rh}-\mathrm{O}^{\mathrm{b}}$ & 1.5 & 2.96 & 0.87 & 9.45 & 1.5 & 3.06 & \\
\hline \multirow[t]{5}{*}{$\mathrm{Rh}_{6}(\mathrm{CO})_{16}$} & $\mathrm{Rh}-\mathrm{Rh}$ & 4.0 & 2.76 & 7.28 & -3.22 & 4.0 & 2.75 & \multirow{5}{*}{$\begin{array}{l}\text { This } \\
\text { work }\end{array}$} \\
\hline & $\mathrm{Rh}-\mathrm{C}^{\mathrm{t}}$ & 2.2 & 1.92 & 5.35 & & 2.0 & 1.92 & \\
\hline & $\mathrm{Rh}-\mathrm{C}^{\mathrm{b}}$ & 1.8 & 2.14 & 7.56 & & 2.0 & 2.18 & \\
\hline & $\mathrm{Rh}-\mathrm{O}^{\mathrm{t}}$ & 2.2 & 3.04 & 3.74 & & 2.0 & 3.04 & \\
\hline & $\mathrm{Rh}-\mathrm{O}^{\mathrm{b}}$ & 1.8 & 3.23 & 1.8 & & 2.0 & 3.34 & \\
\hline
\end{tabular}

${ }^{(1)}$ Notation: $\mathrm{CN}$, coordination number; $R$, distance between the absorber and backscatterer atoms; $\Delta \sigma^{2}$ mean square relative displacement; $\Delta E_{0}$, inner potential correction. Error bounds are estimated as follows: $\mathrm{CN}, \pm 10 \% ; R, \pm 0.02 \AA ; \Delta \sigma^{2}, \pm 20 \% ; \Delta E_{0}, \pm 20 \% .{ }^{(2)} \mathrm{O}_{\text {s }}$ and $\mathrm{O}_{1}$ denote framework oxygen atoms of zeolite $\mathrm{HY} . \mathrm{C}^{\mathrm{t}}$ and $\mathrm{O}^{\mathrm{t}}$ denote carbon and oxygen atoms of terminal carbonyl ligands. $\mathrm{C}^{\mathrm{b}}$ and $\mathrm{O}^{\mathrm{b}}$ denote carbon and oxygen atoms of bridging carbonyl ligands. ${ }^{(3)}$ Fitting range: $k: 4.70-14.70 \AA^{-1} ; R: 0.5-3.5 \AA$.

\section{Formation of $\mathrm{Rh}_{4}(\mathrm{CO})_{12}$ and $\mathrm{Rh}_{6}(\mathrm{CO})_{16}$ from $\mathrm{Rh}(\mathrm{I})(\mathrm{CO})_{2}$ in presence of $\mathrm{CO}+\mathrm{H}_{2} \mathrm{O}$.}

Tetra- and hexa-rhodium clusters can be synthesized from $\mathrm{Rh}(\mathrm{I})(\mathrm{CO})_{2}$ in the supercages of zeolite HY under conditions of the water gas shift reaction, ${ }^{10}$ and we have reproduced the reported results as zeolite-HY-supported $\mathrm{Rh}(\mathrm{I})(\mathrm{CO})_{2}$ was exposed to flowing $\mathrm{CO}$ saturated with water vapor at 35 ${ }^{\circ} \mathrm{C}$ for $8 \mathrm{~h}$, leading to the appearance of IR peaks at 2075, 2044, and $1885 \mathrm{~cm}^{-1}$ that characterize the terminal and bridging $\mathrm{C}-\mathrm{O}$ vibrations of $\mathrm{Rh}_{4}(\mathrm{CO})_{12}$, along with a weak band centered at 1818 $\mathrm{cm}^{-1}$, which characterizes the bridging $\mathrm{C}-\mathrm{O}$ vibration of $\mathrm{Rh}_{6}(\mathrm{CO})_{16}$ (Figure $\mathrm{S} 3$ in the SI). The IR spectrum had stopped changing by the end of the 8 -h treatment. Consistent with reported results, ${ }^{10}$ the IR spectra show that the major cluster product was $\mathrm{Rh}_{4}(\mathrm{CO})_{12}(96 \%)$, with the thermodynamically more stable $\mathrm{Rh}_{6}(\mathrm{CO})_{16}(4 \%)$ appearing as a minor product. 
Conversion of $\mathrm{Rh}_{4}(\mathrm{CO})_{12}$ into $\mathrm{Rh}_{6}(\mathrm{CO})_{16}$ and $\mathrm{Rh}(\mathrm{I})(\mathrm{CO})_{2}$ in wet helium. When the zeolite incorporating $\mathrm{Rh}_{4}(\mathrm{CO})_{12}, \mathrm{Rh}_{6}(\mathrm{CO})_{16}$, and unconverted $\mathrm{Rh}(\mathrm{I})(\mathrm{CO})_{2}(<5 \%)$ was exposed to flowing helium saturated with water vapor at $80{ }^{\circ} \mathrm{C}$, the IR bands representing $\mathrm{Rh}_{4}(\mathrm{CO})_{12}(2075$, 2044, and $1885 \mathrm{~cm}^{-1}$ ) (Figure 1) were gradually replaced by bands at 2117 and $2053 \mathrm{~cm}^{-1}$ characterizing $\mathrm{Rh}(\mathrm{I})(\mathrm{CO})_{2}$ and intense bands at 2080 and $1818 \mathrm{~cm}^{-1}$ and a weak band at $2044 \mathrm{~cm}^{-}$ ${ }^{1}$ characterizing $\mathrm{Rh}_{6}(\mathrm{CO})_{16}$. Because the diameter of a zeolite HY supercage $(\approx 11 \AA)^{20}$ is just slightly greater than the diameter of an $\operatorname{Rh}_{6}(\mathrm{CO})_{16}$ molecule $(\approx 10 \AA)^{21}$ and slightly greater than the diameter of a $\mathrm{Rh}_{4}(\mathrm{CO})_{12}$ molecule $(\approx 9 \AA)^{18}$, and the apertures between the cages have a diameter of $7.4 \AA$, ${ }^{20}$ we infer that the clusters of both kinds were trapped in these cages — and so they must have formed from smaller species in the cages, which suggests the occurrence of cluster fragmentation and migration of mononuclear rhodium species during the treatments.
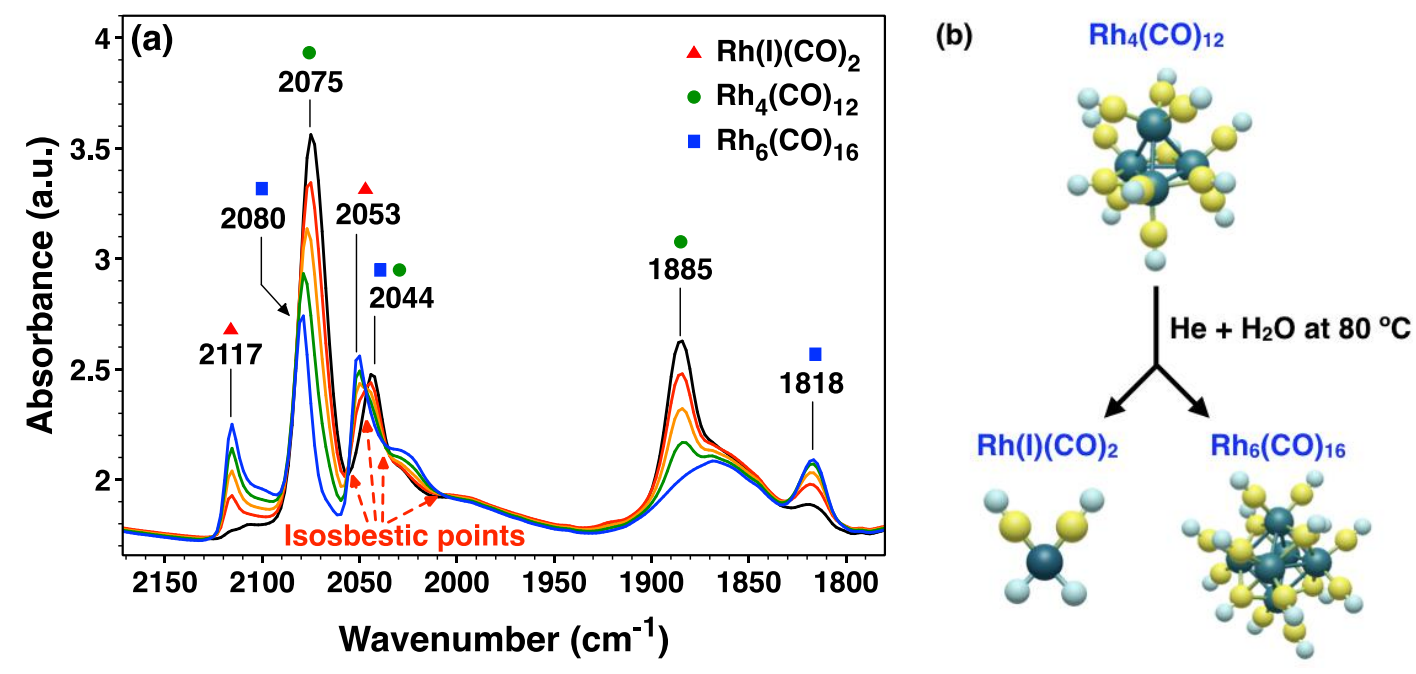

Figure 1. (a) IR spectra showing the process of the formation of $\mathrm{Rh}_{6}(\mathrm{CO})_{16}(\mathbf{m})$ and $\mathrm{Rh}(\mathrm{I})(\mathrm{CO})_{2}$ $(\Delta)$ from $\mathrm{Rh}_{4}(\mathrm{CO})_{12}(\bullet)$ in zeolite HY. The black solid line represents $\mathrm{Rh}_{4}(\mathrm{CO})_{12}$ with the side product $\mathrm{Rh}_{6}(\mathrm{CO})_{16}$ made from supported $\mathrm{Rh}(\mathrm{I})(\mathrm{CO})_{2}$ in zeolite $\mathrm{HY}(\mathrm{Si}$ :Al atomic ratio $=2.6)$ in flowing helium saturated with $\mathrm{H}_{2} \mathrm{O}$ at $80{ }^{\circ} \mathrm{C}$ for $1.5 \mathrm{~h}$. $\mathrm{Rh}_{4}(\mathrm{CO})_{12}$ was gradually converted to a mixture of $\mathrm{Rh}_{6}(\mathrm{CO})_{16}$ and $\mathrm{Rh}(\mathrm{I})(\mathrm{CO})_{2}$ in flowing helium saturated with $\mathrm{H}_{2} \mathrm{O}$ at $80^{\circ} \mathrm{C}$ for periods of 10 (red), 20 (orange), 30 (green), and 90 (blue) min. (b) Schematic representation of the process of converting $\mathrm{Rh}_{4}(\mathrm{CO})_{12}$ to $\mathrm{Rh}_{6}(\mathrm{CO})_{16}$ and $\mathrm{Rh}(\mathrm{I})(\mathrm{CO})_{2}$. 
Maximizing the yield of $\operatorname{Rh}_{6}(\mathbf{C O})_{16}$. Working from these inferences, we hypothesized that the exposure of the supported rhodium carbonyls to helium $+\mathrm{H}_{2} \mathrm{O}$ led to breakup of some of the tetrarhodium clusters to give mononuclear rhodium species that migrated within the zeolite cages/channels and in turn reacted with nearby tetrarhodium species to give hexarhodium species. To test this hypothesis, we repeated the process of making mixtures of $\mathrm{Rh}(\mathrm{I})(\mathrm{CO})_{2}$ and $\mathrm{Rh}_{6}(\mathrm{CO})_{16}$ by exposing the sample to flowing $\mathrm{CO}+\mathrm{H}_{2} \mathrm{O}$ at $35^{\circ} \mathrm{C}$ followed by exposure to flowing helium + $\mathrm{H}_{2} \mathrm{O}$ at $80^{\circ} \mathrm{C}$ - and then we repeated the process 12 times, measuring IR spectra. This sequence led to the results shown in Figure 2, which include $v_{\mathrm{CO}}$ IR spectra indicating that the major product in the zeolite had become $\mathrm{Rh}_{6}(\mathrm{CO})_{16}$. The band intensities lead to an estimated yield of $\mathrm{Rh}_{6}(\mathrm{CO})_{16}$ of $90 \%$. This is the highest yield that we obtained in numerous trials attempting to maximize itsome of the rhodium $(\$ 10 \%)$ always remained in the form of anchored single-site $\mathrm{Rh}(\mathrm{I})(\mathrm{CO})_{2}$.

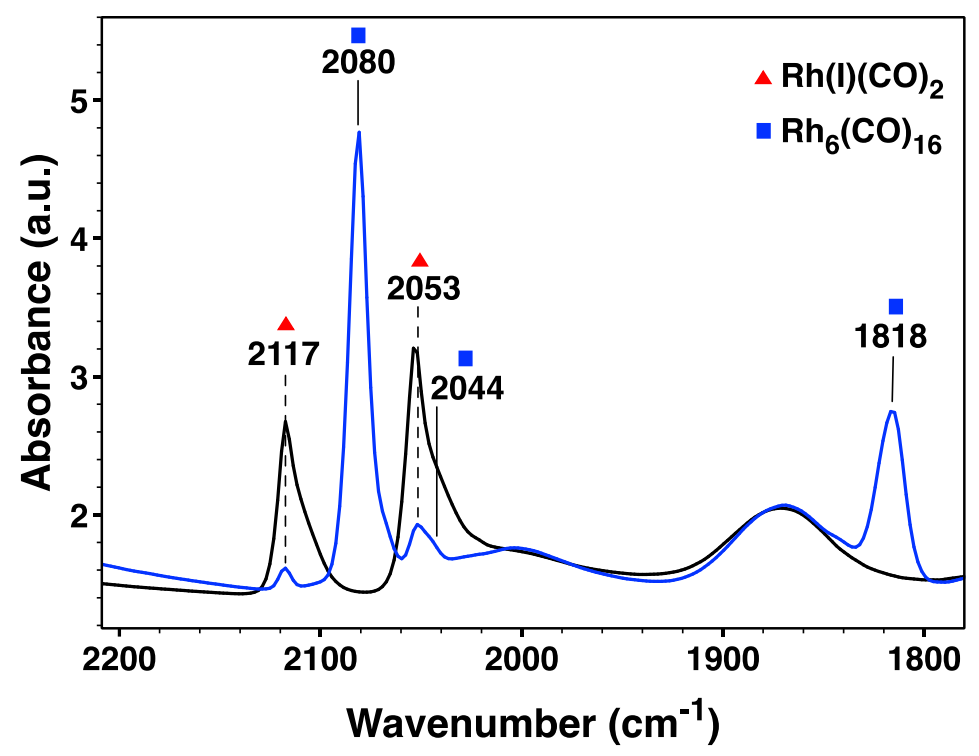

Figure 2. IR spectra of zeolite-supported sample initially containing $\mathrm{Rh}(\mathrm{I})(\mathrm{CO})_{2}$ after exposure to a flowing mixture of $\mathrm{CO}+$ water at $35^{\circ} \mathrm{C}$ for $8 \mathrm{~h}$, followed by flowing mixture of helium + water at $80^{\circ} \mathrm{C}-$ a sequence of treatment steps that was repeated 12 times. The bands at 2117 and 2054 $\mathrm{cm}^{-1}$ characterizing the $\mathrm{Rh}(\mathrm{I})(\mathrm{CO})_{2}$ species declined in intensity as the bands at 2080, 2044, and $1818 \mathrm{~cm}^{-1}$, characterizing $\mathrm{Rh}_{6}(\mathrm{CO})_{16}$ increased. A comparison of the band areas at $2117 \mathrm{~cm}^{-1}$ 
before and after the transformation shows that approximately $90 \%$ of the mononuclear species were converted into these $\mathrm{Rh}_{6}(\mathrm{CO})_{16}$ clusters.

We used EXAFS spectroscopy to further characterize the sample containing predominantly $\mathrm{Rh}_{6}(\mathrm{CO})_{16}$. The structural parameters match within error those determined by X-ray diffraction crystallography for solid $\mathrm{Rh}_{6}(\mathrm{CO})_{16}$. The results thus confirm the IR evidence of $\mathrm{Rh}_{6}(\mathrm{CO})_{16}$.

Reaction network accounting for formation of rhodium carbonyls in zeolite. The data

of Figure 1 show how the mononuclear species was converted in the sequence of treatments to give predominantly $\mathrm{Rh}_{6}(\mathrm{CO})_{16}$. The data indicate that the concentration of $\mathrm{Rh}_{4}(\mathrm{CO})_{12}$ passed through a maximum, demonstrating that it is an intermediate in the reaction scheme. But the data show that the reaction network for cluster formation is not so simple as $\mathrm{Rh}(\mathrm{I})(\mathrm{CO})_{2} \rightarrow \mathrm{Rh}_{4}(\mathrm{CO})_{12}$ $\rightarrow \mathrm{Rh}_{6}(\mathrm{CO})_{16}$ (for simplicity, we omit the co-reactants in this representation). Instead, we infer the reaction network represented in Scheme 1, with the evidence being the following: The initial rate of formation of each of the clusters, $\mathrm{Rh}_{4}(\mathrm{CO})_{12}$ and $\mathrm{Rh}_{6}(\mathrm{CO})_{16}$, from $\mathrm{Rh}(\mathrm{I})(\mathrm{CO})_{2}$ was indistinguishable from zero, consistent with the identification of each cluster as a primary product (Figure 1). However, the data also demonstrate conversion of $\mathrm{Rh}_{4}(\mathrm{CO})_{12}$ to $\mathrm{Rh}_{6}(\mathrm{CO})_{16}$, and so we include the pathway whereby $\mathrm{Rh}_{6}(\mathrm{CO})_{16}$ was formed as a secondary product from $\mathrm{Rh}(\mathrm{I})(\mathrm{CO})_{2}$, with $\mathrm{Rh}_{4}(\mathrm{CO})_{12}$ being a reactive intermediate. The data of Figure 1 also demonstrate that both $\mathrm{Rh}(\mathrm{I})(\mathrm{CO})_{2}$ and $\mathrm{Rh}_{6}(\mathrm{CO})_{16}$ formed from $\mathrm{Rh}_{4}(\mathrm{CO})_{12}$, and so these reactions are included in the network. The data of Figure $\mathrm{S} 4$ in the SI show that $\mathrm{Rh}_{6}(\mathrm{CO})_{16}$, when exposed to flowing helium at $180{ }^{\circ} \mathrm{C}$, was converted into $\mathrm{Rh}(\mathrm{I})(\mathrm{CO})_{2}$, and mass spectra of the effluent gas formed during this fragmentation indicate $\mathrm{H}_{2}$ and $\mathrm{CO}$. These products imply the occurrence of the water gas shift halfreaction shown in the network of Scheme 1. 
The data further indicate that the formation of $\mathrm{Rh}(\mathrm{I})(\mathrm{CO})_{2}$ along with $\mathrm{Rh}_{4}(\mathrm{CO})_{12}$ took place in a stoichiometrically simple reaction, with the evidence being the following: The spectra of Figure 1 characterizing the transformation include isosbestic points, also showing that $\mathrm{Rh}(\mathrm{I})(\mathrm{CO})_{2}$ and $\mathrm{Rh}_{6}(\mathrm{CO})_{16}$ formed at a constant ratio, indicated by the peak heights (and by the peak areas). Specifically, the ratio of the height (or area) of the peaks at 2117 and $1818 \mathrm{~cm}^{-1}$, representing the $\mathrm{C}-\mathrm{O}$ vibrations of $\mathrm{Rh}(\mathrm{I})(\mathrm{CO})_{2}$ (symmetric vibrational mode of terminal $\mathrm{C}-\mathrm{O}$ ligands) and $\mathrm{Rh}_{6}(\mathrm{CO})_{16}$ (vibration of $\mu^{3}$-bridging $\mathrm{C}-\mathrm{O}$ ligands), respectively, was nearly constant during the change.

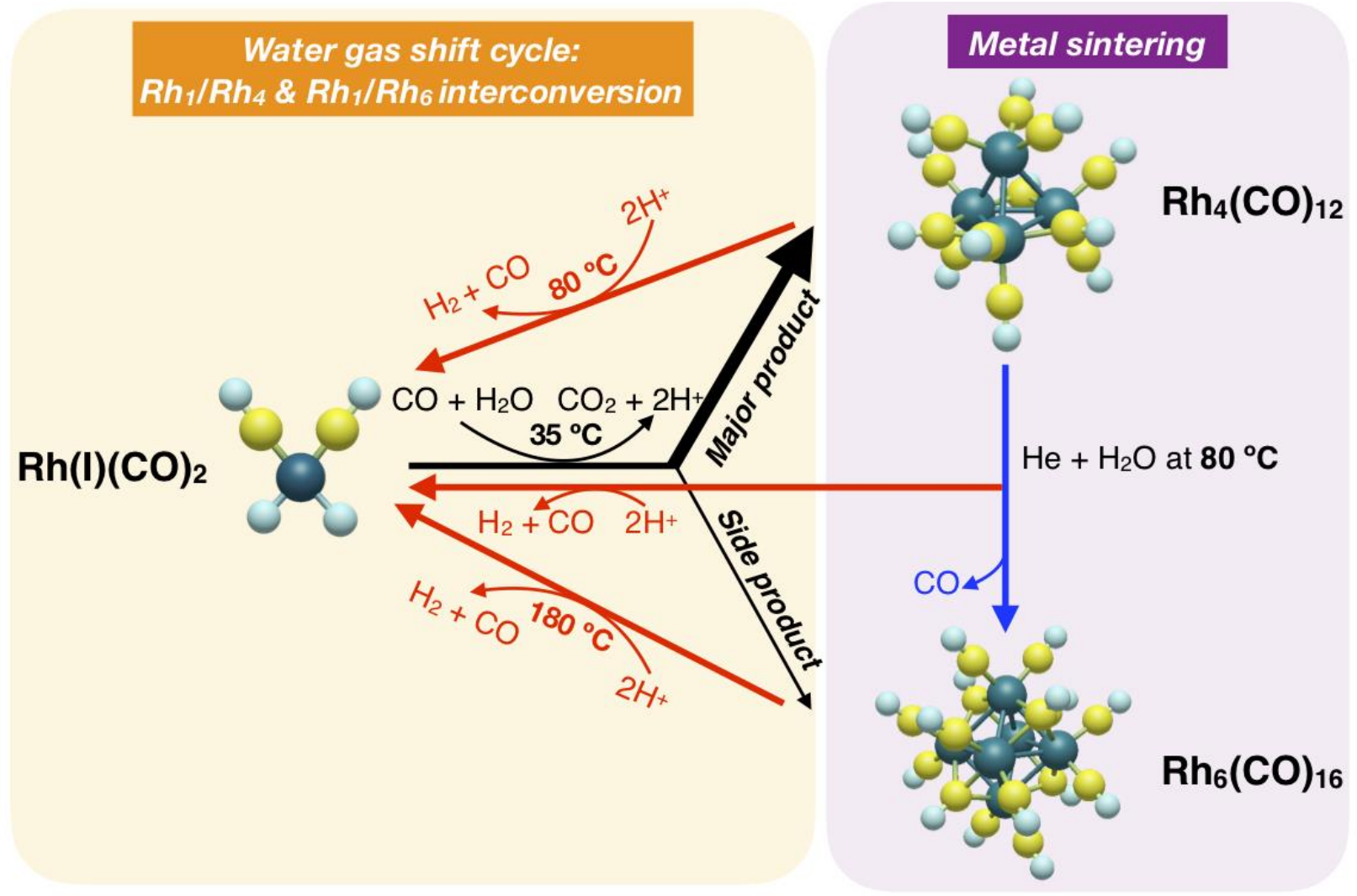

Scheme 1. Schematic representation of the reaction network of the reversible cycle of formation and fragmentation $\mathrm{Rh}_{4}(\mathrm{CO})_{12}$ and $\mathrm{Rh}_{6}(\mathrm{CO})_{16}$ facilitated by the half-reactions of the water gas shift and converting metastable $\mathrm{Rh}_{4}(\mathrm{CO})_{12}$ to the mixture of $\mathrm{Rh}_{6}(\mathrm{CO})_{16}$ and $\mathrm{Rh}(\mathrm{I})(\mathrm{CO})_{2}$. By means of repeating the steps in the treatments (see text), the yield of $\mathrm{Rh}_{6}(\mathrm{CO})_{16}$ in zeolite $\mathrm{HY}$ was maximized. 
Kinetics of reactions in zeolites. The IR spectra provide a basis for quantifying the kinetics of the intrazeolite reactions, as follows: We tracked the evolution with cycles of the maximum intensities measured as peak areas of the IR bands associated with $\mathrm{Rh}(\mathrm{I})(\mathrm{CO})_{2}$ sites $\left(2117 \mathrm{~cm}^{-1}\right)$, $\mathrm{Rh}_{4}(\mathrm{CO})_{12}\left(1885 \mathrm{~cm}^{-1}\right)$, and $\mathrm{Rh}_{6}(\mathrm{CO})_{16}\left(1818 \mathrm{~cm}^{-1}\right)$. Figure 3 shows this evolution for the cluster formation treatment (with the sample initially consisting of $\mathrm{Rh}(\mathrm{I})(\mathrm{CO})_{2}$ ), and comparable results for the fragmentation process (with the sample initially consisting of a mixture of $\mathrm{Rh}_{4}(\mathrm{CO})_{12}$ and $\mathrm{Rh}_{6}(\mathrm{CO})_{16}$ with unconverted $\mathrm{Rh}(\mathrm{I})(\mathrm{CO})_{2}$ also present from the cluster formation treatment). These figures, compared with those based on peak heights rather than areas (shown in Figure S5 of the SI), demonstrate that either basis for analysis leads to the same conclusions. In the stepwise cluster formation process, the data show that the $\mathrm{Rh}_{6}(\mathrm{CO})_{16}$ concentration increased with an increasing number of cycles, whereas the $\mathrm{Rh}_{4}(\mathrm{CO})_{12}$ concentration decreased, with the concentration of $\mathrm{Rh}(\mathrm{I})(\mathrm{CO})_{2}$ being essentially constant. Conversely, in the cluster fragmentation process beginning with predominantly $\mathrm{Rh}(\mathrm{I})(\mathrm{CO})_{2}$, the $\mathrm{Rh}_{6}(\mathrm{CO})_{16}$ concentration increased while the $\mathrm{Rh}(\mathrm{I})(\mathrm{CO})_{2}$ concentration decreased with increasing number of cycles in the cluster fragmentation process. The $\mathrm{Rh}_{6}(\mathrm{CO})_{16}$ clusters were always formed in both cluster formation and fragmentation processes, and the data indicate that most of the $\mathrm{Rh}_{6}(\mathrm{CO})_{16}$ clusters were formed in the fragmentation process. In either case, the bands characterizing these species evolved, appearing or disappearing with time (or number of cycles) until reaching an apparent steady state. Considering the time it takes to reach the steady state in each cycle, we can express the data for each species as a function of the absorbance against time (or number of cycle). Likewise, considering that the absorbance is proportional to the species concentration (according to the Beer-Lambert law), we can write a first- 
order law kinetics equation for each species (details in the SI). The fitting curves are shown in Figure 3.

Analogous chemistry of $\mathrm{Rh}_{6}(\mathrm{CO})_{16}$ formation in high-silica HY zeolite. To test for the importance of zeolite composition on the chemistry, we used for comparison zeolite HY having a $\mathrm{Si}: \mathrm{Al}$ atomic ratio of 30 . First, we treated the anchored $\mathrm{Rh}(\mathrm{I})(\mathrm{CO})_{2}$, made as described above, in flowing $\mathrm{CO}+\mathrm{H}_{2} \mathrm{O}$ at $35^{\circ} \mathrm{C}$ for $72 \mathrm{~h}$. More than $95 \%$ of the initial $\mathrm{Rh}(\mathrm{I})(\mathrm{CO})_{2}$ was selectively converted to $\mathrm{Rh}_{4}(\mathrm{CO})_{12}$, as shown by the IR data, confirming what has been reported. ${ }^{10}$ Thereafter, the sample was treated in flowing helium $+\mathrm{H}_{2} \mathrm{O}$ at $80^{\circ} \mathrm{C}$ for $1.5 \mathrm{~h}$, and the IR spectra show that $\mathrm{Rh}_{4}(\mathrm{CO})_{12}$ was gradually converted to $\mathrm{Rh}_{6}(\mathrm{CO})_{16}$ and $\mathrm{Rh}(\mathrm{I})(\mathrm{CO})_{2}$ (Figure $\mathrm{S} 6$ in the SI). Thus, the data show that the chemistry of converting mononuclear to hexanuclear rhodium in the high-silica zeolite is similar to that occurring in the low-silica zeolite, but in the high-silica zeolite, the cluster formation required a markedly longer time than in the low-silica zeolite (roughly $72 \mathrm{vs} .8 \mathrm{~h}$ ). We infer on the basis of the analogy in the chemistry that after sufficient repetitions of the treatment the yield of $\mathrm{Rh}_{6}(\mathrm{CO})_{16}$ can also be maximized in the high-silica zeolite, but we did not carry out the tedious experiments that would have been needed to determine the maximum yield. 

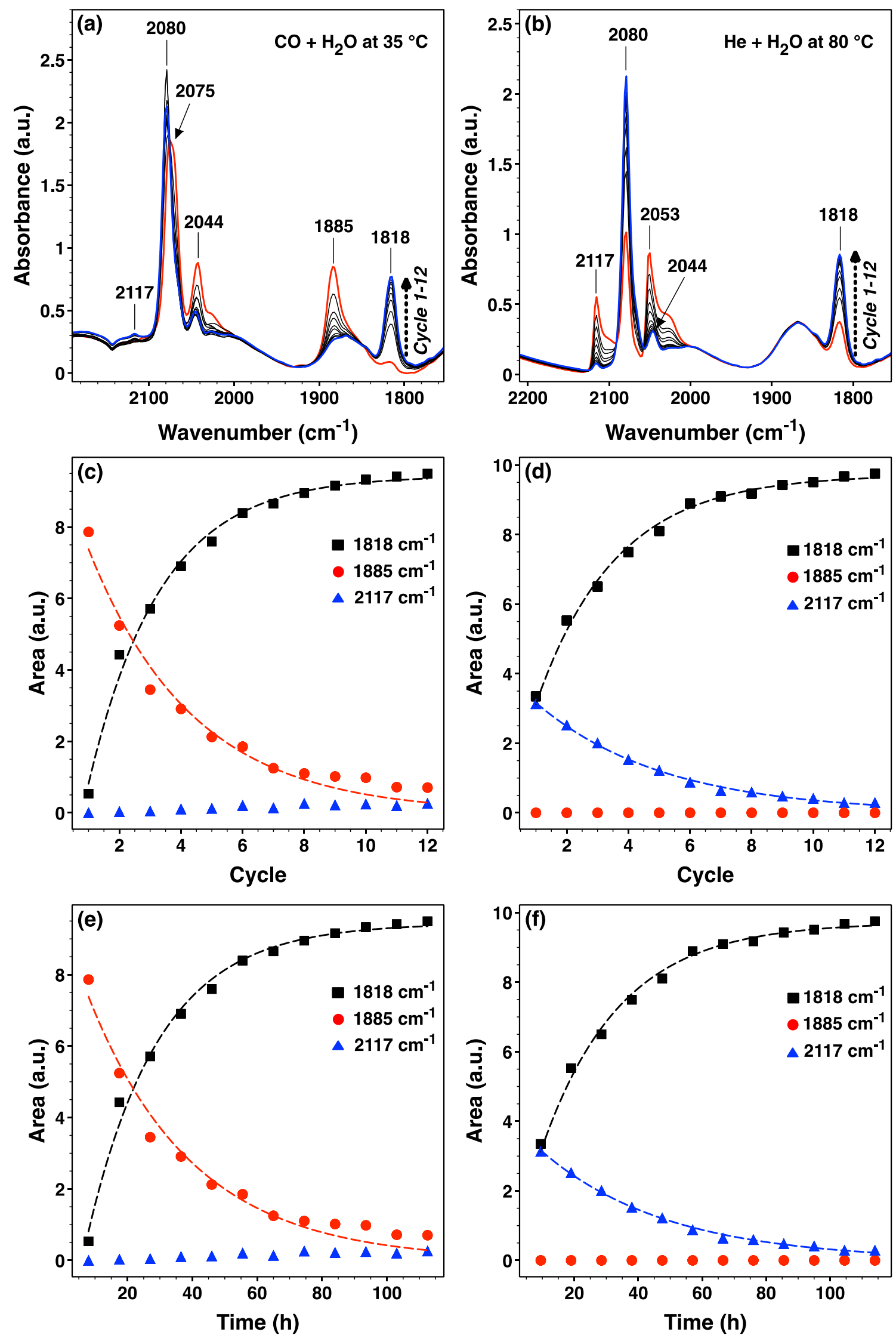
Figure 3. (a) Evolution with 12 cycles of the 1818,1885 and $2117 \mathrm{~cm}^{-1}$ IR bands during the cluster formation treatment. IR spectra characterizing cluster formation and the zeolite HY-supported sample initially incorporating supported $\mathrm{Rh}(\mathrm{I})(\mathrm{CO})_{2}$; the spectra changed as the sample was exposed to flowing $\mathrm{CO}$ saturated with water vapor, whereupon the rhodium species were converted into $\mathrm{Rh}_{6}(\mathrm{CO})_{16}$ in mixtures with $\mathrm{Rh}_{4}(\mathrm{CO})_{12}$, as shown by the appearance of bands characterizing each of these clusters (details in the text). (b) Evolution over 12 cycles of the 1818, 1885, and 2117 $\mathrm{cm}^{-1}$ IR bands during the tetrarhodium cluster breakup. IR spectra characterizing the breakup of $\mathrm{Rh}_{4}(\mathrm{CO})_{12}$ in zeolite $\mathrm{HY}$ in flowing helium $+\mathrm{H}_{2} \mathrm{O}$ at $80{ }^{\circ} \mathrm{C}$, forming mixtures of supported $\mathrm{Rh}(\mathrm{I})(\mathrm{CO})_{2}$ and $\mathrm{Rh}_{6}(\mathrm{CO})_{16}$. The products were identified by characteristic IR bands, as described in the text. (c) and (e) Band areas from (a) showing approximate kinetics of the conversion of $\mathrm{Rh}(\mathrm{I})(\mathrm{CO})_{2}$ to a mixture of $\mathrm{Rh}_{4}(\mathrm{CO})_{12}$ and $\mathrm{Rh}_{6}(\mathrm{CO})_{16}\left[\mathrm{Rh}_{4}(\mathrm{CO})_{12}: \mathrm{Rh}_{6}(\mathrm{CO})_{16}\right.$ molar ratio in the first cycle $\approx 95.6: 4.4]$ in $\mathrm{CO}+$ water at $35^{\circ} \mathrm{C}$. The data show that $\mathrm{Rh}_{4}(\mathrm{CO})_{12}$, represented by the red circles, was a primary product and the predominant product formed initially and that it was converted to $\mathrm{Rh}_{6}(\mathrm{CO})_{16}$, represented by the black squares, and the initial reactant $\mathrm{Rh}(\mathrm{I})(\mathrm{CO})_{2}$, evidently has essentially zero intensity and the essentially zero slope of the fitted curve showing the data after each cycle of cluster formation, suggesting that most $\mathrm{Rh}(\mathrm{I})(\mathrm{CO})_{2}$ complexes were almost fully converted to $\mathrm{Rh}_{4-6}$ clusters under the conditions of the water gas shift reaction. (d) and (f) Band areas from (b) showing the approximate kinetics of the conversion of $\mathrm{Rh}_{4}(\mathrm{CO})_{12}$ to $\mathrm{Rh}_{6}(\mathrm{CO})_{16}$ and $\mathrm{Rh}(\mathrm{I})(\mathrm{CO})_{2}$ in helium $+\mathrm{H}_{2} \mathrm{O}$ at $80{ }^{\circ} \mathrm{C}$.

\section{DISCUSSION}

Pathway for converting $\mathrm{Rh}_{4}(\mathrm{CO})_{12}$ to $\mathrm{Rh}_{6}(\mathrm{CO})_{16}$ in zeolite $\mathrm{HY}$. We previously reported the highly selective and reversible synthesis of $\mathrm{Rh}_{4}(\mathrm{CO})_{12}$ in the supercages of high-silica zeolite HY from chemisorbed $\mathrm{Rh}(\mathrm{I})(\mathrm{CO})_{2}$ complexes under conditions of the water gas shift reaction, with the reverse reaction facilitated by exposure of the sample to dry helium at $80{ }^{\circ} \mathrm{C} .{ }^{10}$ This process was suggested to involve charge transfer between rhodium atoms of $\mathrm{Rh}_{4}(\mathrm{CO})_{12}$ and protons of zeolite Brønsted acid sites. However, when the helium stream contained water at $80{ }^{\circ} \mathrm{C}, \mathrm{Rh}_{4}(\mathrm{CO})_{12}$ was converted to $\mathrm{Rh}(\mathrm{I})(\mathrm{CO})_{2}$ and $\mathrm{Rh}_{6}(\mathrm{CO})_{16}$. The new data reported here show that repetitive stepwise treatments under the water gas shift reaction conditions at $35{ }^{\circ} \mathrm{C}$, followed by fragmentation in a treatment in helium containing water at $80^{\circ} \mathrm{C}$, markedly increased the yield of $\mathrm{Rh}_{6}(\mathrm{CO})_{16}$.

To explain this chemistry, we suggest that, in the presence of water, most of the zeolite hydroxyl groups were covered by chemisorbed water, ${ }^{22,23}$ so that when fragmentation of $\mathrm{Rh}_{4}(\mathrm{CO})_{12}$ 
took place at $80^{\circ} \mathrm{C}$, some of the rhodium carbonyl fragments could not react with the Brønsted acid $\mathrm{OH}$ sites to form anchored $\mathrm{Rh}(\mathrm{I})(\mathrm{CO})_{2}$; instead, they reacted with unconverted $\mathrm{Rh}_{4}(\mathrm{CO})_{12}$ to form more thermodynamically stable clusters, $\mathrm{Rh}_{6}(\mathrm{CO})_{16}$. A similar explanation is valid for other samples in which water competes with reactants or products to be adsorbed on the acidic sites of the zeolites. Thus, for example, when water is cofed in the catalytic methanol-to-hydrocarbons process, the catalytic activity decreases because the reaction equilibrium shifts and because of the competitive adsorption of water, reactants, and products. The latter point has been demonstrated by considering water adsorption terms in kinetics models ${ }^{24}$ and verified by computational results characterizing the competitive adsorption of water and methanol. ${ }^{25}$ Similarly, the adsorption of water on the acidic sites of zeolite HY would be considered to be more favorable in the range of temperatures used in our experiments than the adsorption of $\mathrm{Rh}(\mathrm{I})(\mathrm{CO})_{2}$ species. Accordingly, the water adsorbed on the Brønsted acidic sites of zeolite HY forms water clusters that have low adsorption enthalpies (3.6-10.9 $\left.\mathrm{kJ} \mathrm{mol}^{-1}\right) .{ }^{23}$ Besides having favorable thermodynamics, the water adsorption would be more kinetically favored than the adsorption of $\mathrm{Rh}(\mathrm{I})(\mathrm{CO})_{2}$ species because the latter requires more steps including the breakup of $\mathrm{Rh}_{4}(\mathrm{CO})_{12}$ clusters and the transportation and adsorption of fragments throughout the zeolite porous structure.

\section{Comparison with known chemistry of hexarhodium cluster synthesis via the water}

gas shift reaction. Our results are broadly consistent with the reported solution chemistry whereby $\mathrm{Rh}_{4-6}$ clusters are synthesized from mononuclear rhodium carbonyls in the presence of $\mathrm{H}_{2} \mathrm{O}$ and $\mathrm{CO} .{ }^{26}$ Theolier et $a l .{ }^{27}$ reported comparable chemistry for the synthesis of rhodium clusters on the surfaces of $\gamma-\mathrm{Al}_{2} \mathrm{O}_{3}$ and of $\mathrm{SiO}_{2}$, with the precursor being anchored $\mathrm{Rh}(\mathrm{I})(\mathrm{CO})_{2}$ complexes and the gas-phase reactants being $\mathrm{CO}+\mathrm{H}_{2} \mathrm{O}$; they observed a high-yield conversion to $\mathrm{Rh}_{6}(\mathrm{CO})_{16}$. 
$\mathrm{Rh}_{4}(\mathrm{CO})_{12}$ was evidently present, as indicated by Theolier's IR spectra, which indicated the complete conversion to $\mathrm{Rh}_{6}(\mathrm{CO})_{16}$ after treatment in flowing $\mathrm{CO}+\mathrm{H}_{2} \mathrm{O}$ for $24 \mathrm{~h}$.

In contrast to the results of Theolier et al., we observed that $\mathrm{Rh}_{4}(\mathrm{CO})_{12}$ was quite stable in zeolite $\mathrm{HY}$, not being fully converted to $\mathrm{Rh}_{6}(\mathrm{CO})_{16}$ even after treatment for $24 \mathrm{~h}$. We attribute the difference to the narrow apertures and small cages of the zeolite, in contrast to the larger-pored $\gamma$ $\mathrm{Al}_{2} \mathrm{O}_{3}$ and $\mathrm{SiO}_{2}$, inferring the essential role of the zeolite supercages stabilizing the intrinsically less stable $\mathrm{Rh}_{4}(\mathrm{CO})_{12}$, hindering its transport to the mononuclear rhodium fragments to make the larger clusters. Thus, the results show how the small, confining environments of zeolites allow control of the chemistry and direct the product to one less favored thermodynamically.

In contrast, Weber et al. ${ }^{28}$ observed the facile and direct conversion of physisorbed $\mathrm{Rh}(\mathrm{I})(\mathrm{CO})_{2}$ (acac) (identified by IR spectra) complexes to $\mathrm{Rh}_{6}(\mathrm{CO})_{16}$ in zeolite $\mathrm{NaY}$ under conditions of the water gas shift reaction. All these results taken together indicate that the presence of the confining environment of the faujasite supercages is not alone sufficient to determine the product of cluster formation-because Weber et al. carried out their cluster synthesis with physisorbed mononuclear rhodium carbonyls, in contrast to our chemisorbed $\mathrm{Rh}(\mathrm{I})(\mathrm{CO})_{2}$. The physisorbed species evidently readily overcame the energy barrier to transport within the zeolite, reaching the supercages where hexarhodium clusters formed, whereas the chemisorbed mononuclear rhodium carbonyls in our zeolite had to become unlinked from the surface to be transported to the cages where the clusters formed, and this process was slow, as shown by our kinetics.

To summarize, our observations indicate chemistry that is consistent with earlier work, but the transport influence was markedly different. What primarily sets our work apart from the 
earlier work is the influence of transport limitations in delivering the mononuclear rhodium fragments to the zeolite supercages where $\mathrm{Rh}_{6}(\mathrm{CO})_{16}$ formed.

\section{Reversible process of $\operatorname{Rh}_{6}(\mathrm{CO})_{16}$ formation in zeolite $\mathrm{HY}$ to complete the water gas}

shift cycle. The data presented in Figure S4 in the SI show that $\mathrm{Rh}_{6}(\mathrm{CO})_{16}$ in zeolite $\mathrm{HY}$, when exposed to dry helium at $180{ }^{\circ} \mathrm{C}$, was fully converted to anchored $\mathrm{Rh}(\mathrm{I})(\mathrm{CO})_{2}$, with the formation of effluent gas-phase $\mathrm{H}_{2}$ and $\mathrm{CO}$ detected by mass spectrometry. This process is evidently analogous to the chemistry observed previously ${ }^{10}$ in the reversible conversion of $\mathrm{Rh}(\mathrm{I})(\mathrm{CO})_{2}$ to $\mathrm{Rh}_{4}(\mathrm{CO})_{12}$, involving charge transfer between $\mathrm{Rh}(0)$ in $\mathrm{Rh}_{6}(\mathrm{CO})_{16}$ and protons in acidic $\mathrm{OH}$ groups in the zeolite, leading to oxidative fragmentation of $\mathrm{Rh}_{6}(\mathrm{CO})_{16}$ and generation of $\mathrm{H}_{2}$. Thus, we infer that the interconversion of $\mathrm{Rh}(\mathrm{I})(\mathrm{CO})_{2} / \mathrm{Rh}_{6}(\mathrm{CO})_{16}$ also involves the water gas shift halfreactions that add up to a complete cycle of the water gas shift reaction. The overall water gas shift chemistry for both the $\mathrm{Rh}(\mathrm{I})(\mathrm{CO})_{2} / \mathrm{Rh}_{4}(\mathrm{CO})_{12}$ and $\mathrm{Rh}(\mathrm{I})(\mathrm{CO})_{2} / \mathrm{Rh}_{6}(\mathrm{CO})_{16}$ conversions is summarized in the following equations:

$$
\begin{aligned}
& 4 \mathrm{Rh}(\mathrm{I})(\mathrm{CO})_{2}+2 \mathrm{H}_{2} \mathrm{O}+6 \mathrm{CO} \rightarrow \mathrm{Rh}_{4}(\mathrm{CO})_{12}+4 \mathrm{H}^{+}+2 \mathrm{CO}_{2} \\
& 6 \mathrm{Rh}(\mathrm{I})(\mathrm{CO})_{2}+3 \mathrm{H}_{2} \mathrm{O}+7 \mathrm{CO} \rightarrow \mathrm{Rh}_{6}(\mathrm{CO})_{16}+6 \mathrm{H}^{+}+3 \mathrm{CO}_{2} \\
& \mathrm{Rh}_{4}(\mathrm{CO})_{12}+4 \mathrm{H}^{+} \rightarrow 4 \mathrm{Rh}(\mathrm{I})(\mathrm{CO})_{2}+2 \mathrm{H}_{2}+4 \mathrm{CO} \\
& \mathrm{Rh}_{6}(\mathrm{CO})_{16}+6 \mathrm{H}^{+} \rightarrow 6 \mathrm{Rh}(\mathrm{I})(\mathrm{CO})_{2}+3 \mathrm{H}_{2}+6 \mathrm{CO}
\end{aligned}
$$

Stability of Rh6(CO)16 in zeolite HY depends on its surface chemistry. As shown in Figure S4 in the SI and discussed in the preceding section, $\mathrm{Rh}_{6}(\mathrm{CO})_{16}$ in zeolite $\mathrm{HY}$ is not as stable as $\mathrm{Rh}_{6}(\mathrm{CO})_{16}$ in zeolite $\mathrm{NaY}$. Weber et al. ${ }^{28}$ reported that the $\mathrm{Rh}_{6}(\mathrm{CO})_{16}$ clusters maintained their nuclearity in zeolite $\mathrm{NaY}$ after removal of all the $\mathrm{CO}$ ligands (by treatment in helium at $200{ }^{\circ} \mathrm{C}$ ). This observation is contrasted with ours, which show that $\mathrm{Rh}_{6}(\mathrm{CO})_{16}$ clusters were completely fragmented in zeolite HY under similar conditions. We attribute the difference to the surface 
chemistry associated with the acidic $\mathrm{OH}$ groups in zeolite HY. The chemistry is comparable to that of the oxidative fragmentation of rhodium nanoclusters on the surface of $\gamma-\mathrm{Al}_{2} \mathrm{O}_{3}$ in the presence of $\mathrm{CO},{ }^{29}$ and this is evidently excluded when these acidic groups are not present.

\section{CONCLUSIONS}

The data presented here elucidate the reversible reaction network of conversion of carbonyls of $\mathrm{Rh}_{1}$ to $\mathrm{Rh}_{4}$ to $\mathrm{Rh}_{6}$ in zeolite $\mathrm{HY}$ driven by the water gas shift reaction. $\mathrm{Rh}_{4}(\mathrm{CO})_{12}$ clusters, formed from anchored, site-isolated $\mathrm{Rh}(\mathrm{I})(\mathrm{CO})_{2}$, are intermediates in the formation of $\mathrm{Rh}_{6}(\mathrm{CO})_{16}$ in the zeolite supercages. Rhodium species with various nuclearities- $\mathrm{Rh}_{1}, \mathrm{Rh}_{4}$, and $\mathrm{Rh}_{6}$ - have been precisely synthesized and controlled in these cages with their confining environments, with the stability of the clusters affected by the presence or absence of reactive acidic $\mathrm{OH}$ groups. The kinetics of the conversion from $\mathrm{Rh}_{1}$ to $\mathrm{Rh}_{6}$ was affected by the nature of rhodium-support bonding: chemisorbed rhodium species are more resistant to migration and aggregation than physisorbed rhodium species. The observations point to zeolites as ideal supports for control of the synthesis of supported metal clusters that could serve as novel catalysts for future applications.

\section{ASSOCIATED CONTENT}

Supporting Information. Additional experimental details of IR, mass spectrometry and XAS data are described in the supporting information.

\section{Corresponding Author}

*E-mail: bcgates@ucdavis.edu 


\section{Author Contributions}

$\dagger$ These authors contributed equally.

\section{Funding Sources}

This work was supported by the U.S. Department of Energy (DOE), Office of Science, Basic Energy Sciences (BES) Grant FG02-04ER15513.

\section{Notes}

The authors declare no competing financial interest.

\section{ACKNOWLEDGMENTS}

This work was supported by the U.S. Department of Energy (DOE), Office of Science, Basic Energy Sciences (BES), grant FG02-04ER15513. We acknowledge the support of Ryan Davis and Simon R. Bare and the Co-ACCESS program at beamline 4-1 at the Stanford Synchrotron Radiation Lightsource, supported by DOE, Office of Science, BES, Contract DEAC02-76SF00515.

\section{REFERENCES}

[1] Olah, G. A.; Molnár, A.; Prakash, G. K. Hydrocarbon Chemistry; Wiley: Hoboken, NJ, 2017.

[2] Guisnet, M. “Ideal” Bifunctional Catalysis over Pt-Acid Zeolites. Catal. Today 2013, 218-219, 123-134.

[3] Weitkamp, J. Catalytic Hydrocracking-Mechanisms and Versatility of the Process. ChemCatChem 2012, 4, 292-306. 
[4] Calemma, V.; Peratello, S.; Stroppa, F.; Giardino, R.; Perego, C. Hydrocracking and Hydroisomerization of Long-Chain $n$-Paraffins. Reactivity and Reaction Pathway for Base Oil Formation. Ind. Eng. Chem. Res. 2004, 43, 934-940.

[5] Zeolites and Catalysis: Synthesis, Reactions and Applications; Cejka, J.; Corma, A.; Zones, S., Ed.; Wiley-VCH: Weinheim, 2010.

[6] Moliner, M.; Gabay, J. E.; Kliewer, C. E.; Carr, R. T.; Guzman, J.; Casty, G. L.; Serna, P.; Corma, A. Reversible Transformation of Pt Nanoparticles into Single Atoms inside High-Silica Chabazite Zeolite. J. Am. Chem. Soc. 2016, 138, 15743-15750.

[7] Liu, L.; Lopez-Haro, M.; Lopes, C. W.; Li, C.; Concepcion, P.; Simonelli, L.; Calvino, J. J.; Corma, A. Regioselective Generation and Reactivity Control of Subnanometric Platinum Clusters in Zeolites for High-Temperature Catalysis. Nat. Mater. 2019, 18, 866-874.

[8] Jaeger, N. I.; Jourdan, A.; Schulz-Ekloff, G.; Kleine, A.; Ryder, P. L. The Growth of Platinum Phases within a Faujasite Matrix. Stud. Surf. Sci. Catal., 1988, 37, 191-198.

[9] Guan, E.; Fang, C.-Y.; Yang, D.; Wang, L.; Xiao, F.-S.; Gates, B. C. Supported Cluster Catalysts Synthesized to be Small, Simple, Selective and Stable. Faraday Discuss. 2018, 208, 933.

[10] Fang, C.-Y.; Zhang, S.; Hu, Y.; Vasiliu, M.; Perez-Aguilar, J. E.; Conley, E. T.; Dixon, D. A.; Chen, C.-Y.; Gates, B. C. Reversible Metal Aggregation and Redispersion Driven by the Catalytic Water Gas Shift Half-Reactions: Interconversion of Single-Site Rhodium Complexes and Tetrarhodium Clusters in Zeolite HY. ACS Catal. 2019, 9, 3311-3321.

[11] Rode, E. J.; Davis, M. E.; Hanson, B. E. Propylene Hydroformylation on Rhodium Zeolites X and Y: II In situ Fourier-Transform Infrared-Spectroscopy. J. Catal. 1985, 96, 574-585. 
[12] Kawi, S.; Gates, B. C. Reversible Carbonylation/Decarbonylation of Zeolite-Entrapped Tetrairidium Clusters. Catal. Lett. 1991, 10, 263-270.

[13] Aydin, C.; Lu, J.; Shirai, M.; Browning, N. D.; Gates, B. C. Ir 6 Clusters Compartmentalized in the Supercages of Zeolite NaY: Direct Imaging of a Catalyst with Aberration-Corrected Scanning Transmission Electron Microscopy. ACS Catal. 2011, 1, 1613-1620.

[14] Vityuk, A.; Aleksandrov, H. A.; Vayssilov, G. N.; Ma, S.; Alexeev, O. S.; Amiridis, M. D. Effect of Si/Al Ratio on the Nature and Reactivity of HY Zeolite-Supported Rhodium Dicarbonyl Complexes. J. Phys. Chem. C 2014, 118, 26772-26788.

[15] Hoffman, A. S.; Sokaras, D.; Zhang, S.; Debefve, L. M.; Fang, C.-Y.; Gallo, A.; Kroll, T.; Dixon, D. A.; Bare, S. R.; Gates, B. C. High-Energy-Resolution X-ray Absorption Spectroscopy for Identification of Reactive Surface Species on Supported Single-Site Iridium Catalysts. Chem. Eur. J. 2017, 23, 14760-14768.

[16] Hoffman, A. S.; Fang, C.-Y.; Gates, B. C. Homogeneity of Surface Sites in Supported SingleSite Metal Catalysts: Assessment with Band Widths of Metal Carbonyl Infrared Spectra. J. Phys. Chem. Lett. 2016, 7, 3854-3860.

[17] Lu, J.; Serna, P.; Aydin, C.; Browning, N. D.; Gates, B. C. Supported Molecular Iridium Catalysts: Resolving Effects of Metal Nuclearity and Supports as Ligands. J. Am. Chem. Soc. 2011, 133, 16186-16195.

[18] Farrugia, L. J. Structural Redetermination of $\mathrm{Rh}_{4}(\mathrm{CO})_{12}$ at 293 and $173 \mathrm{~K}$ and Analysis of the Thermal Motion in Relation to the Dynamic Behavior. J. Cluster Sci. 2000, 11, 39-53. [19] Farrar, D. H.; Grachova, E. V.; Lough, A.; Patirana, C.; Poë, A. J.; Tunik, S. P. Ligand Effects on the Structures of $\mathrm{Rh}_{6}(\mathrm{CO})_{15} \mathrm{~L}$ Clusters. J. Chem. Soc., Dalton Trans. 2001, 2015-2019. 
[20] Qin, Z.; Cychosz, K. A.; Melinte, G.; El Siblani, H.; Gilson, J.- P.; Thommes, M.; Fernandez, C.; Mintova, S.; Ersen, O.; Valtchev, V. Opening the Cages of Faujasite-Type Zeolite. J. Am. Chem. Soc. 2017, 139, 17273-17276.

[21] Ichikawa, M. In Chemisorption and Reactivity on Supported Clusters and Thin Films: Towards an Understanding of Microscopic Processes in Catalysis; Lambert, R. M.; Pacchioni, G., Eds.; Springer: Netherlands, 1997; pp 153-192.

[22] Parker, L. M.; Bibby, D. M.; Burns, G. R. Interaction of Water with the Zeolite HY, Studied by FTIR. Zeolites 1991, 11, 293-297.

[23] Simonot-Grange, M.-H.; Elm'Chaouri, A.; Weber, G.; Dufresne, P.; Raatz, F.; Joly, J.-F. Characterization of the Dealumination Effect into H Faujasites by Adsorption: Part 1. The Water Molecule as a Structural Aluminum Ion Selective Probe. Zeolites 1992, 2, 155-159.

[24] Gayubo, A. G.; Aguayo, A. T.; Castilla, M.; Moran, A. L.; Bilbao J. Role of Water in the Kinetic Modeling of Methanol Transformation into Hydrocarbons on HZSM-5 Zeolite. Chem. Eng. Comm. 2004, 191, 944-967.

[25] De Wispelaere, K.; Wondergem, C. S.; Ensing B.; Hemelsoet, K.; Meijer E. J.; Weckhuysen, B. M.; Van Speybroeck, V.; Ruiz-Martinez, J. Insight into the Effect of Water on the Methanolto-Olefins Conversion in H-SAPO-34 from Molecular Simulations and in Situ Microspectroscopy. ACS Catal. 2016, 6, 1991-2002.

[26] Chini, P.; Martinengo, S. Synthesis of Rhodium Carbonyl Compounds at Atmospheric Pressure. III. Synthesis of $\mathrm{Rh}_{4}(\mathrm{CO})_{12}$ and of $\mathrm{Rh}_{6}(\mathrm{CO})_{16}$. Inorg. Chim. Acta 1969, 3, 315-318.

[27] Theolier, A.; Smith, A. K.; Leconte, M.; Basset, J.-M.; Zanderighi, G. M.; Psaro, R.; Ugo, R. Surface Supported Metal Cluster Carbonyls. Chemisorption Decomposition and Reactivity of $\mathrm{Rh}_{4}(\mathrm{CO})_{12}$ Supported on Silica and Alumina. J. Organomet. Chem. 1980, 191, 415-424. 
[28] Weber, W. A.; Gates, B. C. Hexarhodium Clusters in NaY Zeolite: Characteristics by Infrared and Extended X-Ray Absorption Fine Structure Spectroscopies. J. Phys. Chem. B 1997, 101, $10423-10434$.

[29] Suzuki, A.; Inada, Y.; Yamaguchi, A.; Chihara, T.; Yuasa, M.; Nomura, M.; Iwasawa, Y. Time Scale and Elementary Steps of CO-Induced Distintegration of Surface Rhodium Clusters. Angew. Chem., Int. Ed. 2003, 42, 4795-4799. 
TOC Graphic

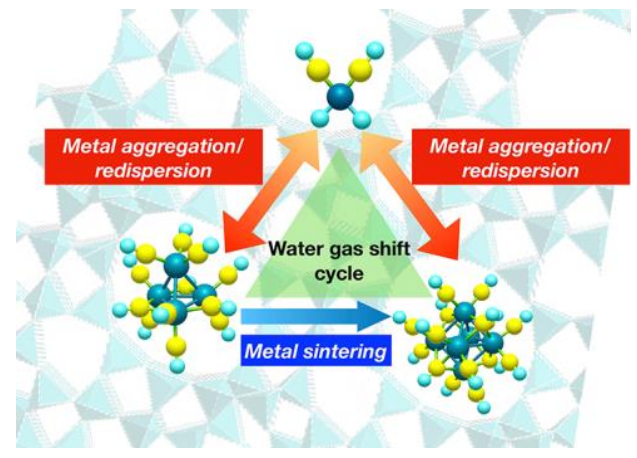

